\title{
Legislative Voting Behaviour in the Regional Party System: An Analysis of Roll-Call Votes in the South Korean National Assembly, 2000-8
}

\begin{abstract}
This article explores legislative voting behaviour in the regional party system where electoral competition is based primarily on geographic divisions instead of national public policies. An analysis of roll-call votes in the National Assembly of the Republic of Korea from 2000 to 2008 reveals that in the regionalized context, legislative voting unity is high because legislators are disciplined to receive endorsement from their regional champion party. Those legislators are far more disciplined when voting on pork legislation. Nonetheless, as the socioeconomic status of constituents rises and the constituents thus care more about policy than pork, then opposition legislators tend to vote against their parties more often. Conversely, governing-party members are more disciplined to pass bills where voters often desire policy over pork. This study suggests a powerful interaction between party affiliations and voter demands as a dominant electoral strategic tool in the regional party system.
\end{abstract}

Keywords: legislative voting behaviour, regional party system, pork legislation, voter demands, party affiliation

ONE OF THE MOST COMMON ASSUMPTIONS IN THE EXISTING STUDIES ON legislative voting is that parties compete over national public policies. The literature thus suggests that party leaders impose discipline on rank-and-file party members to increase party unity in legislative voting, which helps to deliver promised policies to voters (see, e.g., Herron 2002; Hix 2004; Nemoto et al. 2008). In this policy-centric context, a few legislators, who have strong incentives to

* Jae Hyeok Shin is Assistant Professor in the Department of Political Science and International Relations at Korea University. Contact email: shinj@korea.ac.kr.

Hojun Lee is a PhD candidate in the Department of Political Science and International Relations at Korea University. Contact email: hjlee87@korea.ac.kr.

(C) The Authors 2015. Published by Government and Opposition Limited and Cambridge University Press 
cultivate personal reputations instead of party policy reputations, may undermine party voting unity by defecting from the party line. Thus, for example, party unity tends to be lower among legislators under candidate-centred electoral institutions where candidates compete against co-partisans for voter support, because such an institutional setting encourages politicians to seek personal votes rather than party votes (Carey 2007; Carey and Shugart 1995; Samuels 1999; Shugart et al. 2005). Furthermore, parties tend to be less cohesive in lessdeveloped districts where voters often desire particularistic benefits over policy, because legislators often side with the political leaders who offer them access to pork pipelines (see Desposato and Scheiner 2008; Shin 2013).

In contrast to the deep accumulation of knowledge about legislative voting behaviour in the policy-centric context, scholars have paid little attention to legislative behaviour in a pork-centric context. In particular, we know little about how legislators behave in a regional party system where electoral competition is based primarily on geographic divisions. Because politicians are incentivized to deliver local benefits, or pork, to constituents in the regionalized setting, those pre-existing theories would lead us to believe that party voting unity will be low due to political particularism.

In this article, however, we argue that voting unity within parties should also be high in the regional party system, because party labels play a large role in garnering votes, and legislators are thus disciplined to receive endorsement from their regional champion party in the subsequent election. Additionally, those legislators should become far more disciplined when they vote on bills that deliver pork to their provinces. Voting unity across parties should be also high, because legislators do not pay close attention to policy and thus pass almost every bill presented on the floor. Despite this high voting unity within and across parties, opposition legislators might be expected to vote against their parties more frequently where the majority of constituents are well-off and thus care more about policy than pork. Conversely, governing-party members who control the legislative process should be more disciplined to pass bills where voters often desire policy.

To support these arguments, we analyse legislative voting behaviour in a pork-centric context of regionalized party competition, the National Assembly of the Republic of Korea. The Korean legislature is an optimal case for this study, because since the transition to

(C) The Authors 2015. Published by Government and Opposition Limited and Cambridge University Press 
democracy in 1987, electoral competition has been based primarily on the geographic division between Gyeongsang (South-East) and Jeolla (South-West) provinces (see, e.g., Cho 2000; Choi 2012). For example, conservative parties have won almost all legislative seats in Gyeongsang Province, while liberal parties have been dominant in Jeolla Province.

Using original data on the roll-call votes of all National Assembly legislators from 2000 to $2008,{ }^{1}$ we find that in the regional party system, voting against the party majority is indeed rare; nonetheless, as the educational level of constituents increases, opposition party legislators are more likely to defect from the party majority, whereas their governing party counterparts are less likely to do so. These findings suggest a powerful interaction between party affiliations and voter demands as a dominant electoral strategic tool in the regional party system.

The article proceeds as follows. In the next section, we offer an overview of the regional party system in South Korea. In the second section, we provide detailed theories of how legislators vote in the regional party system. Next, we describe the data, statistical models and measures for testing the theories. We present the results of the empirical testing in the following section and discuss the findings and conclude in a final section.

\section{OVERVIEW: THE REGIONAL PARTY SYSTEM AND COHESIVE LEGISLATURE IN SOUTH KOREA}

Since the transition to democracy, major political parties have had a strong regional support base in South Korea (Cho 2000; Choi 2012). That is, Gyeongsang Province has been a stronghold for conservative parties, including the Democratic Justice Party (1987-90), the Democratic Liberal Party (1990-5), the New Korea Party (1995-7), the Grand National Party (1997-2012) and the Saenuri Party (2012-present). Jeolla Province has been dominated by liberal parties, including the Party for Peace and Democracy (1987-91), the Democratic Party (1991-5), the National Congress for New Politics (1995-2000), the New Millennium Democratic Party (2000-7), the United New Democratic Party (2007-8), the Democratic United Party (2011-13) and the New Politics Alliance for Democracy (2014present). Additionally, during most of the post-authoritarian period, 
right-wing regional champion parties existed in Chungcheong (Mid-South) Province, including the New Democratic Republic Party (1987-90), the United Liberal Democrats (1995-2006), the People First Party (2007-8) and the Liberty Forward Party (2008-12).

Despite the conservative-liberal division, those Gyeongsang, Jeolla and Chungcheong parties also need to deliver local benefits to their supporters in the provinces to maintain their dominance (Shin 2013). Moreover, about 80 per cent of South Korean legislators are elected under the single-member district system, which encourages politicians to deliver narrowly targeted benefits - pork to their constituents (Lancaster 1986; Stratmann and Baur 2002). Even though the rest of the legislators are elected from nationwide party lists, until the 2000 congressional elections voters had only one vote for a candidate in a single-member district, which determined a party's seat share from the party list. Since 2004, voters have had two votes - one for a candidate and one for a party; nonetheless, the outcome produced by the party-list component counts for just 20 per cent of all congressional seats. Although a mixed-member electoral system was adopted, the single-member district component is considered far more important than the party-list component in South Korea (see e.g. Brady and Mo 1992; Shin 2011). Due to the regionalized electoral competition and the pork-inducing electoral institution, Korean legislators should have strong incentives to deliver pork rather than policy. Thus, the Gyeongsang-Jeolla divide has been more salient than the conservative-liberal split in the National Assembly (see Hix and Jun 2009).

Another piece of evidence for pork-centric politics in South Korea is that there is little obstructionism in legislative voting. In an extremely pork-centric legislature (such as the Philippine House of Representatives), most bills are passed with few objections because legislators do not pay close attention to policy and tend to vote with the president, who controls access to pork pipelines (see Shin Forthcoming). The Korean legislature does not seem very different from this pork-dominant legislature.

Figure 1 shows the proportion of roll-call voted bills and resolutions that received simple majority consent, over 95 per cent consent and unanimous consent, respectively, from the 16th National Assembly during Kim Dae-jung's presidency (June 2000-February 


\section{Figure 1}

Roll-Call Voted Bills and Resolutions in the South Korean National Assembly, 2000-8

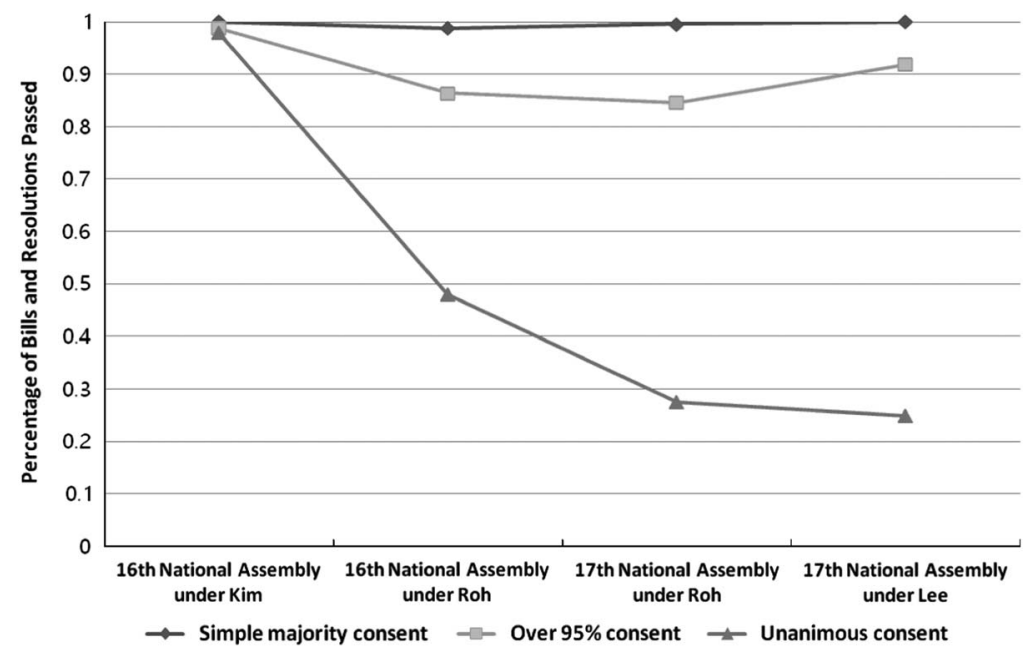

2003) until the 17th National Assembly during Lee Myung-bak's (February-May 2008).

The data set includes 3,737 bills and resolutions, of which just 14 were voted down. Particularly in the 16th National Assembly under Kim $(n=853)$ and in the 17th National Assembly under Lee $(n=173)$, all 1,026 bills and resolutions presented on the floor were passed, indicating that the National Assembly faced very little obstructionism in legislative voting (see Appendix, Table A1). More striking is that, although the percentage of bills and resolutions passed with unanimous consent decreased over time, on average, 88.4 per cent of bills and resolutions were passed with over 95 per cent consent. That is, most of the time, the Korean legislators voted affirmatively on bills and resolutions, regardless of whether they were with the president or in the opposition.

Figure 1 also reveals, however, that except for the 16th National Assembly under Kim Dae-jung, more than half of bills did receive at least one negative vote. Who cast these negative votes in this highly cohesive legislature? That is, who would deviate from the preferences of the legislative majority, to deviate from their party majority in legislative voting? The subsequent section suggests a general theory to address these questions. 


\section{A THEORY OF LEGISLATIVE VOTING BEHAVIOUR IN REGIONAL PARTY SYSTEMS}

In a national party system where major parties are fairly competitive in most areas of the country, parties need to deliver benefits to the broad population, and they thus tend to focus on the delivery of national public policies, or policy. Legislators then have to pass bills in the parliament to deliver policy; thus, party leaders often impose strong discipline on rank-and-file party members to facilitate the passage of bills. Accordingly, party unity in legislative voting tends to be high in such policy-centric contexts (see, e.g., Carey 2007). Conversely, in a regional party system, where different parties are dominant in different parts of the country, those regional champion parties should focus more on the delivery of local benefits, or pork, to safeguard their strongholds in the region. In this environment, one might expect party voting unity to be lower, because politicians would pay little attention to policy; thus, party leaders would not need to impose strong discipline frequently in legislative voting.

In contrast to these expectations, however, voting unity within parties (not to mention across parties) should also be high in a pork-centric system, in part because politicians pass just about any bill presented on the floor of the legislature (see Figure 1, also Shin Forthcoming). Moreover, when the party leaders do impose discipline over some significant bills, those who are elected in their parties' regional strongholds are especially unlikely to defect from the party line, because being endorsed by their regional champion party is of critical importance in winning the subsequent election. Furthermore, the legislators who are elected in the parties' regional strongholds in particular should be far less likely to defect when casting a roll-call vote on legislation that aims to deliver pork to their provinces. Thus, in a pork-centric regionalized setting, party voting unity is expected to be high, just as it is in the policy-centric context, although the mechanisms leading to the outcome differ. To be specific, in a regional party system we expect:

Hypothesis 1.1: Legislators who are elected in their party's regional strongholds are less likely to defect from the party majority's preferences in legislative voting.

Hypothesis 1.2: Legislators who are elected in their party's regional strongholds are far less likely to defect from the party majority's preference when voting on pork legislation for their provinces.

(C) The Authors 2015. Published by Government and Opposition Limited and Cambridge University Press 
Despite this strong party voting unity, whether a legislator is in the opposition or the ruling party may affect her decision whether to defect. In pork-centric systems, politicians within governing parties may be more disciplined than their counterparts in the opposition, because the former can be granted access to government resources for pork (see Shin Forthcoming). Furthermore, in a pork-centric legislature, the government has tight control over the legislative process because few legislators pay close attention to policy. In the National Assembly of South Korea, from 2000 to 2008, for example, about 43 per cent of bills were proposed by the government. Nonetheless, many of the bills proposed by legislators are drafted originally by the government and submitted through the legislators. Even when legislators draft a bill, most of the time the bill can go through a committee only after government agents stationed in its subcommittees have approved it. The government indeed plays a dominant role in making laws in the South Korean regional party system (see, e.g., Park 1998).

Thus, sometimes opposition legislators who want to deliver policy instead of pork to their constituents may have strong incentives to vote against bills, or to voice their opposition, in the pork-centric legislature controlled by the government. Because the majority of parliamentary members, including the opposition, almost always pass any bill presented on the floor, those opposition legislators voting against bills should appear to deviate from the party majority in legislative voting.

A legislator's party affiliation, therefore, is expected to have different effects on the legislator's voting behaviour, depending on her constituents' demands for pork or policy. The voters' demands stem mainly from their socioeconomic conditions. For example, well-educated, well-off voters often desire policy over pork (Banfield and Wilson, 1963; Scott, 1972; Shin, 2015), so sometimes politicians elected from more developed districts have strong incentives to object to a policy that may conflict with the interests of their constituents (Shin Forthcoming). Thus, as the socioeconomic status of constituents rises and they care more about policy than pork, the incentive of opposition legislators to vote against their parties is expected to increase. In contrast to those opposition politicians, members of the governing party should have little incentive to defect from the party majority even when constituents desire policy, because the voters who voted for the president's party candidate should 
expect to receive the promised policy (on top of pork) from the president (Shin 2013). Thus, we would expect governing-party members to be even more disciplined in legislative voting when their constituents demand policy.

Hypothesis 2: As voters' socioeconomic conditions improve, governing-party members are less likely, but opposition-party members are more likely, to defect from the party majority's preferences in legislative voting.

\section{DATA, MODEL AND MEASURES}

To examine legislative voting behaviour in the regional party system, we built an original data set of roll-call votes of all legislators on bills and resolutions in the 16th National Assembly (2000-4) and the 17th National Assembly (2004-8). To test the suggested hypotheses about who would defect from the party majority, we created a dependent variable, Defect $_{i j}$, a dummy variable indicating whether legislator $i$ defects from the preference of the party majority when casting a roll-call vote on bill $j^{2}{ }^{2}$ In the National Assembly, an active abstention (pushing the abstention button) is considered an opposition to the bill, because active abstentions count towards the total votes cast, and a bill must receive more than 50 per cent 'yes' votes to be passed (see Nemoto 2009: 214). Thus, we treat an active abstention in the same way as a 'no' vote. Defect $_{i j}$ is coded 1 if a roll-call vote of the legislator differs from those of the party majority; 0 otherwise. Of the observations in the data set, 3.62 per cent are coded 1. Because the dependent variable is binary, we use a logistic regression model as follows.

$$
\begin{aligned}
\text { Defect }_{i j}= & \beta_{0}+\beta_{1} * \text { Regional Champion Party }_{i j}+\beta_{2} * \text { Pork Legislation }_{i j} \\
& +\beta_{3} * \text { Regional Champion Party }_{i j} * \text { Pork Legislation }_{i j} \\
& +\beta_{4} * \text { Party Affiliations }_{i j}+\beta_{5} * \text { Voter Demands }_{i j} \\
& +\beta_{6} * \text { Party Affiliations }_{i j} * \text { Voter Demands }_{i j}+\beta_{7} * \text { Controls }_{i j}+\varepsilon_{i j}
\end{aligned}
$$

where $\varepsilon$ represents the random error term. 


\section{Regional Champion Parties and Pork Legislation}

From 2000 to 2008, regional champion parties were established along geographic divisions in Jeolla, Gyeongsang and Chungcheong. Jeolla $_{i j}$ is coded 1 if legislator $i$ who was elected in Jeolla Province affiliated with the Millennium Democratic Party (2000-4), Uri Party (2003-7), Democratic Party (2004-7 and 2007-8), Centrist Reformers (2007), Centrist Reform Democratic Party (2007), United New Democratic Party (2007-8) or United Democratic Party (2008), when casting a roll-call vote on bill $j ; 0$ otherwise. Gyeongsang $g_{i j}$ is coded 1 if legislator $i$ elected in Gyeongsang Province affiliated with the Grand National Party, and 0 otherwise. Finally, Chungcheong $g_{i j}$ is coded 1 if legislator $i$ in Chungcheong Province affiliated with the United Liberal Democrats (2000-6), People First Party (2007-8) or Liberty Forward Party (2008), and 0 otherwise. It is expected that those regional champion party variables will have negative effects on Defect $_{i j}$ (Hypothesis 1.1).

Additionally, we generated three dummy variables for legislation that aims to deliver local projects (pork) to the strongholds of the regional champion parties: Pork(Jeolla), Pork(Gyeongsang) and Pork (Chungcheong). ${ }^{3}$ Pork (Jeolla $)_{i j}$, for example, is coded 1 if legislator $i$ casts a roll-call vote for bill $j$ that contains provisions of targeted benefits for Jeolla Province, and 0 otherwise. We then interact the pork legislation variables with the regional champion party variables to test the hypothesis that the legislators elected in their parties' regional strongholds are far less likely to vote against their parties when voting on pork bills for their provinces. The expectation is thus that the interaction terms - Jeolla ${ }_{i j}{ }^{*}$ Pork $(\text { Jeolla })_{i j}$, Gyeongsang ${ }_{i j}{ }^{*}$ Pork

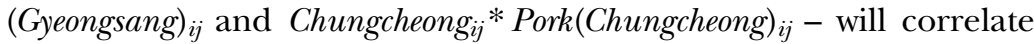
negatively with Defect ${ }_{i j}$ (Hypothesis 1.2).

\section{Party Affiliations and Voter Demands}

Whether a legislator is in the governing party or the opposition may affect her incentive to defect from the party majority in legislative voting. Government ${ }_{i j}$ is coded 1 if legislator $i$ affiliated with the president's party (when casting a roll-call vote on bill $j$ ), and 0 otherwise. Opposition $i j$ is coded 1 if legislator $i$ was in the opposition, and 0 otherwise. Of the observations, 54.6 per cent are coded 1 for 
Opposition $_{i j}$. Independents and legislators with small parties, those with fewer than three members, are excluded because it is impossible to know the preference of the party majority in legislative voting for those politicians.

It is expected, however, that a politician's party affiliation would interact with the socioeconomic status of her constituents in affecting the politician's legislative voting behaviour. We rely on the mean education level of voters in each district as a proxy for voter demands, because no other measures such as family income and urbanization are available at the district level. We also rely on mean education level because less-educated voters tend to be poorer and thus prefer pork over policy, whereas more-educated voters tend to be more well-off and prefer policy over pork (Shin ,2015; Stokes 2005). Education represents the proportion of legislator $i$ 's constituents who received tertiary education, beyond high school, including college, university and vocational schools. We use district-level census data, and the proportion varies from 0.09 to 0.76 , with a mean of 0.38 , in the dataset. $^{4}$

We then interact the proxy for constituent demands $\left(\right.$ Education $\left._{i j}\right)$ with the legislator's party affiliation (Government ${ }_{i j}$ or Opposition $_{i j}$ ); the expectation is that Education $_{i j}{ }^{*}$ Government $_{i j}$ will correlate negatively and Education $_{i j}{ }^{*}$ Opposition $_{i j}$ will correlate positively with Defect ${ }_{i j}$ (Hypothesis 2).

\section{Control Variables}

First, we control for government bills. Government bill $_{j}$ is coded 1 if bill $j$ was proposed by the government or a governing-party legislator, and 0 otherwise. Of all the observations, 55.9 per cent are coded 1 . Because governing-party legislators are more likely to help pass government bills, when this variable is interacted with the party affiliation variables it is expected that Government $_{i j}{ }^{*}$ Government bill $_{i j}$ will correlate negatively, but Opposition $_{i j} *$ Government bill $_{i j}$ will correlate positively with Defect $_{i j}$.

Second, electoral institutions should be controlled for. Since the 1988 National Assembly elections, about 80 per cent of legislators have been elected from single-member districts, while the rest are elected from nationwide party lists. Party-centred electoral institutions such as closed-list proportional representation encourage 
politicians to seek party votes rather than personal votes (Carey 2007; Carey and Shugart 1995; Samuels 1999; Shugart et al. 2005). It is thus expected and corroborated by existing studies that in mixed-member electoral systems the legislators elected from the party lists are less likely to vote against their parties than the legislators elected in the single-member districts (Haspel et al. 1998; Sieberer 2010; Thames 2005). List ${ }_{i}$ is coded 1 if legislator $i$ was elected from a party list; 0 otherwise. The expectation is thus that List $_{i}$ will correlate negatively with Defect .

Third, we include a variable for legislators' ideological positions. A legislator would be more likely to defect from the party majority in legislative voting as the distance between her ideological position and that of the party increases. We use Jung-ang Ilbo's survey on legislators' ideological positions in the 16th and 17th National Assemblies, which is a unidimensional eight-item scale from 1 to 8 , where 1 is the most liberal and 8 is the most conservative. We measure a party's ideological position in terms of the average of ideological positions of all members of the party. Ideological Distance $e_{i}$ is the gap between the ideological positions of legislator $i$ and that of her party. It varies from 0.02 to 4.43 , with a mean of 0.93 . We expect Ideological Distance $e_{i}$ to have a positive effect on Defect . $_{\text {. }}$.

Fourth, party leadership should be less likely to defect from the party majority in roll-call voting because they are the ones who make the party position on significant bills and impose discipline on the rank and file to follow the party line. Most studies code party leadership considering official party posts, such as the party chair, whip and general secretary (e.g. Nemoto 2009). The composition of the leadership of a party changes frequently, however, and senior party members without any official posts in the party may often influence decisions of the party. Hence, we used seniority as a proxy for party leadership. The expectation is that the longer a legislator has served in the legislature, the more influential she is likely to be in making decisions in her party. Seniority $y_{i}$ is the total number of terms legislator $i$ has served in the National Assembly. It varies from 1 to 9, with a mean of 1.62. Seniority is $_{i}$ expected to correlate negatively with Defect . $_{\text {. }}$

Fifth, the Democratic Labour Party (DLP) is considered the only programmatic party in the 16th and 17th National Assemblies (2000-8). When a party focuses on the delivery of policy, rank-and-file party members tend to be more disciplined in facilitating the passage of 
bills (see, e.g., Carey 2007). $D L P_{i j}$ is coded 1 if legislator $i$ is with the Democratic Labour Party when roll-call voting on bill $j$, and 0 otherwise. This variable is expected to have a negative effect on Defect $_{i j}$.

Finally, we control for legislative session fixed effects. The legislative context also varies with different presidents. In South Korea, because presidents are elected for a five-year term, while legislators have a four-year term, presidential and legislative elections are not synchronized. During the 16th and 17th National Assemblies (June 2000 to May 2008), Kim Dae-jung was in the presidency until February 2003, Roh Moo-hyun until February 2008, and Lee Myung-bak until May 2008. We thus include four dummy variables 16th National Assembly under Kim, 16th National Assembly under Roh, 17th National Assembly under Roh, and 17th National Assembly under Lee - in the models to control for unobservable factors specific to each legislative context. In the analysis, the 16th National Assembly under Kim is used as the reference period.

\section{EMPIRICAL RESULTS}

Table 1 shows model estimations of voting defection in the National Assembly from 2000 to 2008. Overall, they matched our expectations. In the regional party system, politicians who are elected in their parties' regional strongholds are less likely to defect from the party majority, and the signs on Jeolla and Chungcheong are thus negative and significant. Contrary to our expectation, however, it appears that politicians from Gyeongsang who affiliate with their regional champion party (Grand National Party) are more likely to defect, as the sign on Gyeongsang is positive. Nevertheless, those Gyeongsang legislators are less likely to deviate from their party majority when voting on pork legislation as the signs on Gyeongsang * Pork(Gyeongsang) are negative and significant. Moreover, as voters' socioeconomic conditions improve, governing-party legislators are less likely but opposition legislators are more likely to defect from the party majority; the coefficients on Education * Government are negative and significant, while those on Education * Opposition are positive and significant.

Column 1 of Table 1 displays the impacts of politicians' affiliations with regional champion parties on their legislative behaviour: legislators of Jeolla parties from their regional strongholds are 1.48 times and their

(C) The Authors 2015. Published by Government and Opposition Limited and Cambridge University Press 
Table 1

Voting Defection in the National Assembly of the Republic of Korea, 2000-2008

\begin{tabular}{|c|c|c|c|c|c|c|}
\hline & Model 1 & Model 2 & Model 3 & Model 4 & Model 5 & Model 6 \\
\hline \multicolumn{7}{|c|}{ Regional champion parties and pork legislations } \\
\hline Jeolla & $\begin{array}{c}-0.39 * * \\
(0.04)\end{array}$ & $\begin{array}{l}-0.37 * * \\
(0.05)\end{array}$ & & & $\begin{array}{l}-0.27 * * \\
(0.05)\end{array}$ & $\begin{array}{l}-0.27 * * \\
(0.05)\end{array}$ \\
\hline Gyeongsang & $\begin{array}{l}0.38^{* *} \\
(0.02)\end{array}$ & $\begin{array}{l}0.40^{* *} \\
(0.02)\end{array}$ & & & $\begin{array}{c}0.03 \\
(0.03)\end{array}$ & $\begin{array}{c}0.03 \\
(0.03)\end{array}$ \\
\hline Chungcheong & $\begin{array}{c}-0.78 * * \\
(0.12)\end{array}$ & $\begin{array}{c}-0.77^{* * *} \\
(0.13)\end{array}$ & & & $\begin{array}{l}-1.14^{* * *} \\
(0.13)\end{array}$ & $\begin{array}{c}-1.14^{* *} \\
(0.13)\end{array}$ \\
\hline Pork (Jeolla $)$ & & $\begin{array}{c}0.24 \\
(0.16)\end{array}$ & & & $\begin{array}{c}0.25 \\
(0.16)\end{array}$ & $\begin{array}{c}0.25 \\
(0.16)\end{array}$ \\
\hline Pork(Gyeongsang) & & $\begin{array}{l}-1.14^{* *} \\
(0.19)\end{array}$ & & & $\begin{array}{l}-1.18 * * \\
(0.19)\end{array}$ & $\begin{array}{l}-1.18^{* *} \\
(0.19)\end{array}$ \\
\hline Pork(Chungcheong) & & $\begin{array}{l}1.08^{* * *} \\
(0.11)\end{array}$ & & & $\begin{array}{l}1.12 * * \\
(0.11)\end{array}$ & $\begin{array}{l}1.12 * * \\
(0.11)\end{array}$ \\
\hline Jeolla * Pork $($ Jeolla $)$ & & $\begin{array}{c}-0.32 \\
(0.20)\end{array}$ & & & $\begin{array}{c}-0.35^{\dagger} \\
(0.20)\end{array}$ & $\begin{array}{c}-0.35^{\dagger} \\
(0.20)\end{array}$ \\
\hline Gyeongsang * Pork (Gyeongsang) & & $\begin{array}{l}-0.35^{* *} \\
(0.10)\end{array}$ & & & $\begin{array}{l}-0.33^{* *} \\
(0.10)\end{array}$ & $\begin{array}{l}-0.33^{* *} \\
(0.10)\end{array}$ \\
\hline Chungcheong * Pork(Chungcheong) & & $\begin{array}{c}-0.11 \\
(0.52)\end{array}$ & & & $\begin{array}{c}-0.11 \\
(0.52)\end{array}$ & $\begin{array}{c}-0.11 \\
(0.52)\end{array}$ \\
\hline \multicolumn{7}{|l|}{ Party affiliations and voter demands } \\
\hline Education & & & $\begin{array}{l}0.51 * * \\
(0.09)\end{array}$ & $\begin{array}{c}-0.61 * * \\
(0.19)\end{array}$ & $\begin{array}{c}0.26 * \\
(0.10)\end{array}$ & $\begin{array}{l}-1.00 * * \\
(0.21)\end{array}$ \\
\hline Government & & & $\begin{array}{c}-0.07 \\
(0.09)\end{array}$ & & $\begin{array}{c}-0.00 \\
(0.09)\end{array}$ & \\
\hline Education* Government & & & $\begin{array}{l}-1.15^{* *} \\
(0.21)\end{array}$ & & $\begin{array}{l}-1.29 * * \\
(0.22)\end{array}$ & \\
\hline
\end{tabular}


Table 1 (Continued)

\begin{tabular}{|c|c|c|c|c|c|c|}
\hline & Model 1 & Model 2 & Model 3 & Model 4 & Model 5 & Model 6 \\
\hline Opposition & & & & $\begin{array}{c}0.08 \\
(0.09)\end{array}$ & & $\begin{array}{c}0.02 \\
(0.09)\end{array}$ \\
\hline Education * Opposition & & & & $\begin{array}{l}1.11^{* * *} \\
(0.21)\end{array}$ & & $\begin{array}{l}1.25^{* *} \\
(0.22)\end{array}$ \\
\hline \multicolumn{7}{|l|}{ Controls } \\
\hline Government Bill & $\begin{array}{l}0.07 * * \\
(0.02)\end{array}$ & $\begin{array}{l}0.07 * * \\
(0.02)\end{array}$ & $\begin{array}{l}0.24 * * \\
(0.02)\end{array}$ & $\begin{array}{c}-0.35^{* *} \\
(0.04)\end{array}$ & $\begin{array}{l}0.24 * * \\
(0.02)\end{array}$ & $\begin{array}{l}-0.34 * * \\
(0.04)\end{array}$ \\
\hline Government $*$ Government Bill & & & $\begin{array}{c}-0.58^{* *} \\
(0.04)\end{array}$ & & $\begin{array}{c}-0.58 * * \\
(0.04)\end{array}$ & \\
\hline Opposition * Government Bill & & & & $\begin{array}{l}0.58^{* * *} \\
(0.04)\end{array}$ & & $\begin{array}{c}0.58 * \\
(0.04)\end{array}$ \\
\hline Party List & $\begin{array}{l}0.16^{* * *} \\
(0.03)\end{array}$ & $\begin{array}{c}0.16^{* * *} \\
(0.03)\end{array}$ & $\begin{array}{l}0.07 * * \\
(0.03)\end{array}$ & $\begin{array}{l}0.07^{* * *} \\
(0.03)\end{array}$ & $\begin{array}{c}0.04 \\
(0.03)\end{array}$ & $\begin{array}{c}0.04 \\
(0.03)\end{array}$ \\
\hline Ideological Distance & $\begin{array}{l}0.07 * * \\
(0.01)\end{array}$ & $\begin{array}{l}0.07 * * \\
(0.01)\end{array}$ & $\begin{array}{l}0.08^{* *} \\
(0.01)\end{array}$ & $\begin{array}{l}0.08^{* *} \\
(0.01)\end{array}$ & $\begin{array}{l}0.08 * * \\
(0.01)\end{array}$ & $\begin{array}{l}0.08 * * \\
(0.01)\end{array}$ \\
\hline Seniority & $\begin{array}{l}-0.07 * * \\
(0.01)\end{array}$ & $\begin{array}{l}-0.07 * * \\
(0.01)\end{array}$ & $\begin{array}{l}-0.09 * * \\
(0.01)\end{array}$ & $\begin{array}{l}-0.09 * * \\
(0.01)\end{array}$ & $\begin{array}{l}-0.10 * * \\
(0.01)\end{array}$ & $\begin{array}{l}-0.10^{* *} \\
(0.01)\end{array}$ \\
\hline$D L P$ & $\begin{array}{l}-0.48^{* *} \\
(0.07)\end{array}$ & $\begin{array}{c}-0.48^{* *} \\
(0.07)\end{array}$ & $\begin{array}{l}-0.84^{* *} \\
(0.07)\end{array}$ & $\begin{array}{c}-0.84^{* *} \\
(0.07)\end{array}$ & $\begin{array}{l}-0.85^{* *} \\
(0.07)\end{array}$ & $\begin{array}{l}-0.85^{* *} \\
(0.07)\end{array}$ \\
\hline 16th NA under Roh & $\begin{array}{c}-0.75^{* *} \\
(0.07)\end{array}$ & $\begin{array}{c}-0.75^{* *} \\
(0.07)\end{array}$ & $\begin{array}{c}-0.81 * * \\
(0.07)\end{array}$ & $\begin{array}{c}-0.81 * * \\
(0.07)\end{array}$ & $\begin{array}{c}-0.82 * * \\
(0.07)\end{array}$ & $\begin{array}{c}-0.82 * * \\
(0.07)\end{array}$ \\
\hline 17th NA under Roh & $\begin{array}{l}-1.19 * * \\
(0.06)\end{array}$ & $\begin{array}{l}-1.20 * * \\
(0.06)\end{array}$ & $\begin{array}{c}-1.15^{* *} \\
(0.06)\end{array}$ & $\begin{array}{c}-1.15^{* * *} \\
(0.06)\end{array}$ & $\begin{array}{l}-1.14 * * \\
(0.06)\end{array}$ & $\begin{array}{l}-1.14^{* *} \\
(0.06)\end{array}$ \\
\hline 17th NA under Lee & $\begin{array}{l}-1.69 * * \\
(0.08)\end{array}$ & $\begin{array}{c}-1.70 * * \\
(0.08)\end{array}$ & $\begin{array}{c}-1.59 * * \\
(0.08)\end{array}$ & $\begin{array}{c}-1.59 * * \\
(0.08)\end{array}$ & $\begin{array}{c}-1.58 * * \\
(0.08)\end{array}$ & $\begin{array}{c}-1.58 * * \\
(0.08)\end{array}$ \\
\hline Constant & $\begin{array}{l}-2.20^{* * *} \\
(0.07)\end{array}$ & $\begin{array}{l}-2.22 * * \\
(0.07)\end{array}$ & $\begin{array}{l}-2.13 * * \\
(0.08)\end{array}$ & $\begin{array}{c}-2.20^{* * *} \\
(0.10)\end{array}$ & $\begin{array}{l}-2.00^{* *} \\
(0.08)\end{array}$ & $\begin{array}{c}-2.02 * * \\
(0.10)\end{array}$ \\
\hline Log-likelihood $=$ & -46013 & -45963 & -45417 & -45417 & -45283 & -45284 \\
\hline
\end{tabular}

Note: $n=294,280 ; \dagger p<0.10, * p<0.05, * * p<0.01 ;$ Standard errors in parentheses. 
Chungcheong counterparts are 2.18 times less likely to defect from the party majority than are the others. Conversely, legislators of the Grand National Party (GNP) from Gyeongsang are 46 per cent more likely to defect from the party majority. When the affiliations with regional champion parties are interacted with pork legislation, however, those Grand National Party legislators from Gyeongsang are 2.97 times less likely to defect from the party majority when voting on bills that aim to deliver pork to the province (column 2 of Table 1). Although statistically insignificant, Jeolla party legislators from Jeolla are 1.57 times less likely to defect, and Chungcheong party legislators from Chungcheong are 0.82 times more likely to defect when voting on pork legislation for their provinces.

Columns 3 and 4 of Table 1 show the interactive impacts of legislators' party affiliation and their constituents' average educational level on the politicians' legislative voting behaviour. To avoid the multicollinearity problem, the dummy variables for governing-party members and opposition-party members are not included in the same model. The impacts are substantial. An easy way to understand the coefficients is by comparing the legislative behaviour of four hypothetical legislators: one governing-party legislator $\left(\mathrm{G}_{10}\right)$ and one opposition legislator $\left(\mathrm{O}_{10}\right)$ from a less developed district where only 10 per cent of voters have received tertiary education beyond high school, and one governing-party legislator $\left(\mathrm{G}_{60}\right)$ and one opposition legislator $\left(\mathrm{O}_{60}\right)$ from a more developed district where 60 per cent of the voters have completed some form of tertiary education. $G_{60}$ is 1.39 times less likely to defect from the party majority than $\mathrm{G}_{10}{ }^{5}$ indicating that legislators with the ruling party become more cohesive in legislative voting as their constituents' education level increases. Conversely, $\mathrm{O}_{60}$ is 1.26 times more likely to defect than $\mathrm{O}_{10},{ }^{6}$ indicating that legislators in the opposition become less cohesive as constituents' education level increases.

Models 5 and 6 include both the regional champion party/pork legislation and the party affiliation/voter demands variables. First, regional champion parties influence the probability of voting defection. Jeolla party members in their regional strongholds are 1.31 times and Chungcheong party members in their strongholds are 3.13 times less likely to defect from the party majority, all other things being equal. Politicians in Gyeongsang who are with its regional party (the Grand National Party), however, show little difference in the likelihood of voting defection from the others. Second, voting on 
pork legislation increases the effects of regional champion party affiliation. When voting on bills to deliver pork, Jeolla party members from their regional strongholds are 1.45 times, and Gyeongsang party members from the province are 4.39 times less likely to defect from the party majority. The interactive effects are not significant for their Chungcheong counterparts, however. Finally, as the education level of voters increases, governing party legislators are less likely and opposition party members are more likely to defect from the party majority, holding other factors constant. For example, the probability of voting defection of a governing-party legislator elected from the more developed constituency $\left(\mathrm{G}_{60}\right)$ is 40 per cent lower than that of a governing-party member from the less developed constituency $\left(\mathrm{G}_{10}\right)$, ceteris paribus. ${ }^{7}$ In contrast, among the opposition politicians, $\mathrm{O}_{60}$ is 13 per cent more likely to defect than $\mathrm{O}_{10}$, all else being equal. ${ }^{8}$

Using a Monte Carlo simulation (based on Model 6), Figure 2 shows how an interaction between politicians' party affiliations and voters' demands influences the legislators' voting behaviour. As the average voter's education level increases and she thus desires more policy than pork, governing-party legislators are less likely, but their opposition counterparts are more likely, to defect from the party line.

Hence, the gap between the opposition and the governing party widens as the education level increases. In less developed districts, where 20 per cent of voters have received tertiary education, such as Hongcheon and Hwaengsung, for example, the predicted probability of their representatives to defect from the party majority is 4.1 per cent if they are in the opposition; the probability is 3.2 per cent if they are in the president's party. That is, in the poorer districts the difference in the predicted probability of voting defection between the opposition and ruling party legislators is just 0.9 per cent, which indicates that where voters tend to desire pork over policy, politicians' legislative behaviour is similar in terms of how likely they are to defect from the party line irrespective of whether they are with the president or not.

It is noteworthy that the party affiliation has considerably greater effects on the probability of voting defection in more developed districts. Where 70 per cent of voters have received tertiary education, such as Gangnam, for example, the disparity in voting defection rate between the opposition and governing-party politicians increases to 2.7 per cent. That difference is statistically significant and also substantial, given that in the highly cohesive legislature politicians 
Figure 2

Party Affiliations, Voter Demands and Legislative Voting Behaviour

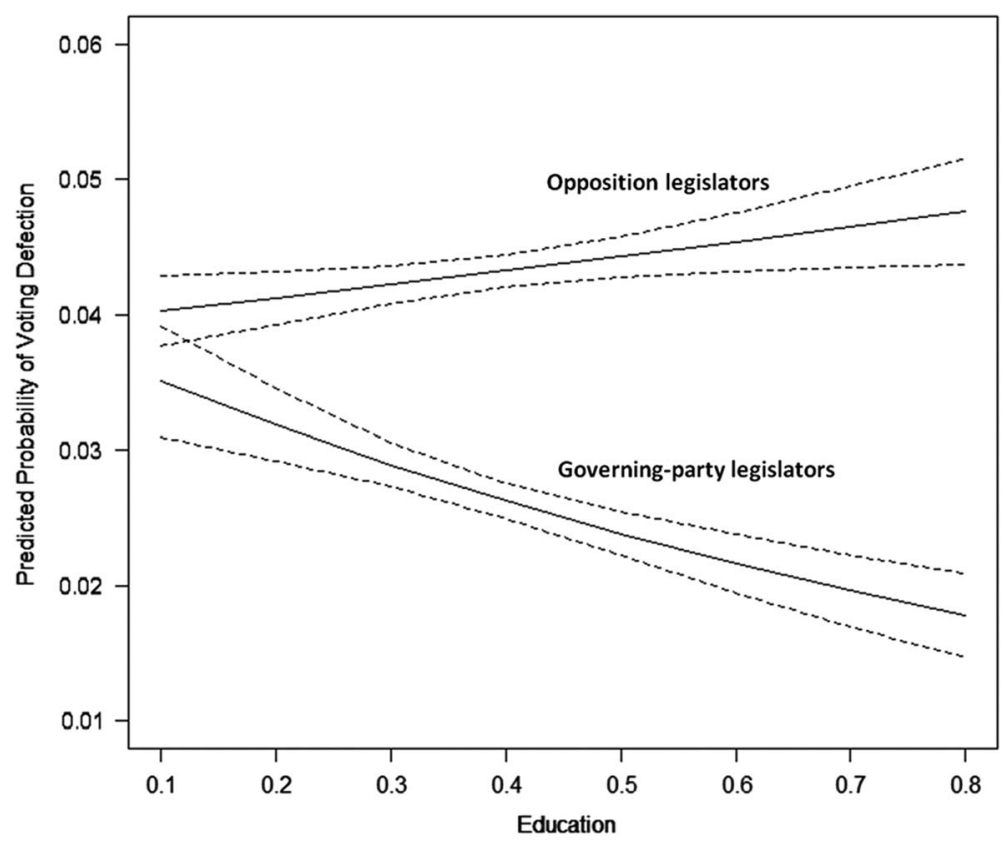

defect from their parties only 3.6 per cent of the time. The findings of this analysis thus signify that opposition legislators are far more likely to vote against their parties than governing-party legislators in more developed districts where most constituents are well educated and thus tend to care more about policy.

In addition, the positive signs on the party-list variable deserve attention. Contrary to expectations from the pre-existing studies that show that the legislators elected from party lists are less likely to defect from their parties than are the legislators elected from singlemember districts, legislators elected from the Korean party list are more likely to defect, although it is not statistically significant when both the regional champion party/pork legislation and the party affiliation/voter demands variables are included in the models. ${ }^{9} \mathrm{Jun}$ and Hix (2010) also find that party-list legislators are more likely to defect from their parties in the National Assembly, arguing that this is because those party-list legislators tend to seek careers outside the 
party after their terms end. Another possible explanation would be that since the National Assembly is pork-centric, those party-list legislators are more likely to vote against the preferences of their party majority because they should respond to the interests of the broader population instead of the narrow incentives of their regional strongholds, which would lead them to vote against the pork-centric incentives of their party majority. The result may thus signify that in regional party systems where most politicians strive to deliver pork, the legislators who are elected by the broader population tend to seek policy when on the floor of the legislature, which is consistent with the findings from the pork-dominant legislature in the Philippines (Shin Forthcoming).

The negative signs on the three legislative session variables - the 16th National Assembly under Roh, the 17th National Assembly under Roh and the 17th National Assembly under Lee - also deserve special attention. As the reference period is the 16th National Assembly under Kim, the results indicate that legislators were less likely to vote against their parties after Kim Dae-jung's presidency (1997-2002). Kim was the regional boss whose stronghold was Jeolla Province, while the previous president Kim Young-sam (1992-7) was the head of Gyeongsang Province. Since the exit of those regional bosses, ideology and generational differences have affected voters' electoral choices to a greater extent (see, e.g., Kim et al. 2008). Thus, the less frequent party defection by legislators may signify that legislators become more disciplined to follow party ideology and policy in the era of the post-regional bosses.

Finally, because most legislators vote more than once during a legislative session, the observations are not independent. Thus, the results of the logit models are compared with those of fixed-effects logit models, eliminating the dummies for the legislative session fixed effects. ${ }^{10}$ The results of both kinds of models are similar, and hence the concern of the non-independent observations can be safely disregarded.

\section{CONCLUSIONS}

This article has explored legislators' voting behaviour in the regional party system where major parties dominate over challengers in their regional strongholds. Using original data on roll-call votes in the 
National Assembly of the Republic of Korea from 2000 to 2008, we find that in South Korea's regional party system, legislators who are elected in a party's regional strongholds tend to be more highly disciplined, so they are less likely to defect from the party majority. Additionally, those legislators are far more disciplined when voting on legislation that delivers pork to their provinces. Moreover, where the majority of voters are well educated and thus assumed to desire policy over pork, legislators in the opposition are more likely to vote against their parties. In contrast, governingparty legislators are more willing to help pass bills where policy is desired.

We make three contributions through this analysis. First, the article expands the study of legislative voting to regional party systems. Previous studies on legislative behaviour usually investigate voting defection on the assumption that parties compete over policy. They argue that in a policy-centric system, politicians tend to be highly disciplined to facilitate the passage of bills. We demonstrate that in the pork-centric setting, politicians are highly disciplined as well, because party labels play a dominant role in garnering votes - a similar outcome resulting from a different causal mechanism.

Second, this study sheds light on an interaction between politicians' party affiliations and voters' demands in explaining the legislative behaviour. Desposato (2006) argued that opposition legislators in less developed districts tended to deviate from the party majority more frequently, because the majority of their constituents demand pork, which leads them to vote with the political leader who controls access to pork pipelines. In contrast, Shin (Forthcoming) demonstrates that in the extremely pork-centric, or pork-dominant, system of the Philippine House of Representatives, where no partyline voting takes place whatsoever and legislators simply pass almost every bill submitted on the House floor, it is the opposition legislators in more developed districts who tend to deviate from the parliamentary majority, because they sometimes have a reason to reject a policy bill. The analysis of roll-call votes in the regional party system of South Korea seems comparable to the study of the pork-dominant system of the Philippines in the sense that, in Korea, legislators pass most bills and opposition legislators are more likely to deviate from the party majority in more developed districts. Nonetheless, in the pork-dominant system of the Philippines, not only opposition legislators but governing-party legislators tend to deviate frequently in 
more developed districts, because they also have strong incentives to voice opposition in the extremely homogeneous parliament dominated by pork-seeking politicians. Conversely, in the regional party system of South Korea, or in a less pork-centric context, governing-party legislators tend to be highly cohesive in legislative voting to help pass policy bills controlled by the government.

Finally, these findings indicate that politicians do pay attention to what voters want when they cast a roll-call vote in the legislature. In less developed districts where voters demand pork over policy, little difference in legislative voting behaviour exists between legislators with the ruling party and those in the opposition. It is in more developed districts where voters often desire policy that the legislative behaviours diverge between those the groups of politicians. This article, therefore, offers some insight into why parties often do not differ substantively in their policies in less developed countries, and suggests that voters' socioeconomic conditions should be improved to promote policy-centric party competition in the developing world.

\section{NOTES}

${ }^{1}$ No roll-call voting took place before 2000 in the National Assembly.

${ }^{2}$ We thus exclude bills and resolutions that passed with unanimous consent.

${ }^{3}$ Out of 3,737 bills and resolutions passed in the National Assembly from 2000 to 2008, 102 were aimed at offering pork.

${ }^{4}$ In South Korea, a census takes place every five years at the administrative district level. We thus reassembled the census data at the electoral district level and used the average of 2000 and 2005 data for the 16th National Assembly (2000-4) and the 2005 data for the 17th National Assembly (2004-8). For metropolitan areas where administrative districts have multiple sub-electoral districts (e.g. Gangnam Gap, Gangnam Eul), we used the administrative-level data for all the sub-electoral districts.

${ }^{5} \operatorname{Prob}_{\mathrm{G} 60}($ Defect $)=0.023 ; \operatorname{Prob}_{\mathrm{G} 10}($ Defect $)=0.032$.

${ }^{6} \operatorname{Prob}_{\mathrm{O} 60}($ Defect $)=0.048 ; \operatorname{Prob}_{\mathrm{O} 10}($ Defect $)=0.038$.

$7 \operatorname{Prob}_{\mathrm{G} 60}($ Defect $)=0.021 ; \operatorname{Prob}_{\mathrm{G} 10}($ Defect $)=0.035$.

${ }^{8} \operatorname{Prob}_{\mathrm{O} 60}($ Defect $)=0.045 ;$ Prob $_{\mathrm{O} 10}($ Defect $)=0.040$.

${ }^{9}$ Rich (2014) also finds no statistically significant difference in voting defection based on seat type in the 17th National Assembly. We find, however, that there is a statistically significant difference in the 16th and 17th National Assemblies, as shown in columns 1-4 of Table 1.

10 This is why the study does not use a fixed-effects logit model - doing so would eliminate the control variables for the legislative sessions.

(C) The Authors 2015. Published by Government and Opposition Limited and Cambridge University Press 
Table A1

Roll-Call Voted Bills and Resolutions in the National Assembly of Republic of Korea, 2000-8

\begin{tabular}{lllr}
\hline National Assembly & $100 \%$ & $>95 \%$ & $>50 \%$ \\
\hline 16th under Kim Dae-jung (June 2000-February 2003) & 0.980 & 0.988 & 1.000 \\
16th under Roh Moo-hyun (February 2003-May 2004) & 0.480 & 0.864 & 0.988 \\
17th under Roh Moo-hyun (June 2004-February 2008) & 0.275 & 0.846 & 0.996 \\
17th under Lee Myung-bak (February 2008-May 2008) & 0.249 & 0.919 & 1.000 \\
Total & 0.462 & 0.884 & 0.996 \\
\hline
\end{tabular}

\section{APPENDIX}




\section{REFERENCES}

Banfield, E. and Wilson, J. (1963), City Politics (Cambridge, MA: Harvard University Press). Brady, D. and Mo, J. (1992), 'Electoral Systems and Institutional Choice: A Case Study of the 1988 Korean Elections', Comparative Political Studies, 24(4): 405-29.

Carey, J. (2007), 'Competing Principals, Political Institutions, and Party Unity in Legislative Voting', American Journal of Political Science, 51 (1): 92-107.

— and Shugart, M.S. (1995), 'Incentives to Cultivate a Personal Vote: A Rank Ordering of Electoral Formulas', Electoral Studies, 14(4): 417-39.

Cho, G.S. (2000), Regionalistic Elections and Rational Voters (in Korean) (Seoul: Nanam). Choi, J.J. (2012), Democracy after Democratization: The Korean Experience (Stanford, CA: Shorenstein Asia-Pacific Research Center).

Desposato, S. (2006), 'Parties for Rent? Ambition, Ideology, and Party Switching in Brazil's Chamber of Deputies', American Journal of Political Science, 50(1): 62-80.

— and Scheiner, E. (2008), 'Governmental Centralization and Party Affiliation: Legislator Strategies in Brazil and Japan', American Political Science Review, 102(4): 509-24.

Haspel, M., Remington, T.F. and Smith, S.S. (1998), 'Electoral Institutions and Party Cohesion in the Russian Duma', Journal of Politics, 60 (2): 417-39.

Herron, E. (2002), 'Electoral Influences on Legislative Behavior in Mixed-Member Systems: Evidence from Ukraine's Verkhovna Rada', Legislative Studies Quarterly, 27(3): 361-82.

Hix, S. (2004), 'Electoral Institutions and Legislative Behavior: Explaining Voting Defection in the European Parliament', World Politics, 56(2): 194-223.

— and Jun, H.W. (2009), 'Party Behaviour in the Parliamentary Arena: The Case of the Korean National Assembly', Party Politics, 15(6): 667-94.

Jun, H.W. and Hix, S. (2010), 'Electoral Systems, Political Career Paths and Legislative Behavior: Evidence from South Korea's Mixed-Member System', Japanese Journal of Political Science, 11(2): 153-71.

Kim, H.M., Choi, J.Y. and Cho, J. (2008), 'Changing Cleavage Structure in New Democracies: An Empirical Analysis of Political Cleavages in Korea', Electoral Studies, 27(1): 136-50.

Lancaster, T. (1986), 'Electoral Structures and Pork Barrel Politics', International Political Science Review, 7(1): 67-81.

Nemoto, K. (2009), 'Committing to the Party: The Costs of Governance in East Asian Democracies', unpublished PhD thesis, San Diego, University of California.

—_ Krauss, E. and Pekkanen, R. (2008), 'Policy Dissension and Party Discipline: The July 2005 Vote on Postal Privatization in Japan', British Journal of Political Science, 38(3): 499-525.

Park, C.M. (1998), 'Executive Predominance over Legislature: Change and Continuity' (in Korean), Korean Journal of Legislative Studies, 4(2): 6-30.

Rich, T.S. (2014), 'Party Voting Cohesion in Mixed Member Legislative Systems: Evidence from Korea and Taiwan', Legislative Studies Quarterly, 39(1): 113-35.

Samuels, D.J. (1999), 'Incentives to Cultivate a Party Vote in Candidate-centric Electoral Systems: Evidence from Brazil', Comparative Political Studies, 32(4): 487-518.

(C) The Authors 2015. Published by Government and Opposition Limited and Cambridge University Press 
Scott, J. (1972), Comparative Political Corruption (Englewood Cliffs, NJ: Prentice-Hall). Shin, J.H. (2011), 'The Choice of Electoral Systems in New Democracies: A Case Study of South Korea in 1988', Democratization, 18(6): 1246-69.

(2013), 'Voter Demands, Access to Resources, and Party Switching: Evidence from the South Korean National Assembly, 1988-2008', Japanese Journal of Political Science, 14(4): 453-72.

(2015), 'Voter Demands for Patronage: Evidence from Indonesia', Journal of East Asian Studies, 15(1): 127-51.

- (Forthcoming), 'Legislative Voting in the Pork-Dominant Parliament: Evidence from the Philippine House of Representatives, 1987-2007', Journal of Legislative Studies.

Shugart, M.S, Valdini, M.E. and Suominen, K. (2005), 'Looking for Locals: Voter Information Demands and Personal Vote-Earning Attributes of Legislators under Proportional Representation', American Journal of Political Science, 49(2): 437-49.

Sieberer, U. (2010), 'Behavioral Consequences of Mixed Electoral Systems: Deviating Voting Behavior of District and List MPs in the German Bundestag', Electoral Studies, 29(3): 484-96.

Stokes, S. (2005), 'Perverse Accountability: A Formal Model of Machine Politics with Evidence from Argentina', American Political Science Review, 99(3): 315-25.

Stratmann, T. and Baur, M. (2002), 'Plurality Rule, Proportional Representation, and the German Bundestag: How Incentives to Pork-Barrel Differ across Electoral Systems', American Journal of Political Science, 46(3): 506-14.

Thames, F.C. (2005), 'A House Divided: Party Strength and the Mandate Divide in Hungary, Russia, and Ukraine’, Comparative Political Studies, 38(3): 282-303. 